\title{
ARQUITETURA DA COMPLEXIDADE: DESIGN À SERVIÇO DA VIDA EM UM ES- TUDO DE CASO NO SUL DE MINAS GERAIS
}

\author{
Evandro de Castro Sanguinetto \\ Biólogo (Licenciatura), Especialista em Meio Ambiente e Recursos Hídricos, MSc em Ciências do \\ Meio Ambiente e Recursos Hídricos, Vice-Presidente do Circuito Turístico Caminhos do Sul de Minas \\ e Conselheiro do CBH-Sapucaí \\ E-mails: evandro@gaiaterranova.com.br e evandrosanguinetto@hotmail.com
}

\section{Resumo}

A complexidade crescente da sociedade humana pede por novas formas de ser, estar, viver e conviver no e com o planeta, superando velhos modelos e padrões de entendimento de mundo baseados no mecanicismo, reducionismo e fracionamento do saber e fazer. Essas novas formas apontam para os processos vivos, a biosfera, como fonte de inspiração e conhecimento para as produções humanas. Propõe-se nesse artigo uma arquitetura biofílica, integrativa, respondente aos padrões, ciclos, teias e redes estabelecidos pela evolução dos seres vivos em sintonia com o planeta que nos abriga. Uma Arquitetura da Complexidade, que incorpore a inter, multi e transdisciplinaridade, as inteligências múltiplas, os diferentes saberes e fazeres resultantes da interação entre culturas e ecossistemas locais, são mediados ou conduzidos pelo design ecológico. Buscando respostas, refletimos, dentre outras questões, sobre a possibilidade de uma arquitetura que formulasse um espaço habitável como parte de um ecossistema, que se expandisse para além de si mesma e reverberasse com o terreno que, em sintonia retroalimentasse o ambiente construído. Como resultado, desenvolvemos e implantamos Gaia Terranova, experimento teórico-prático-vivencial localizado no Sul de Minas Gerais.

Palavras-chave: arquitetura, complexidade, transdisciplinaridade, Gaia Terranova, design ecológico, sustentabilidade. 


\title{
ARCHITECTURE OF COMPLEXITY: DESIGN AIMED AT SERVING LIFE IN A CASE STUDY IN THE SOUTH OF MINAS GERAIS
}

\begin{abstract}
The growing complexity of human society asks for new ways of being and living in and with the planet, overcoming old models and standards for a deeper understanding of the world based on mechanicism, reductionism and fractionism of knowledge and action. This new lifestyle points to living processes - the biosphere, as a source of inspiration and knowledge for human productions. In this study we propose a biophilic and integrative architecture, respondent to standards, cycles, webs and nets established by the evolution of human beings in syntony with the planet sheltering us all. The Architecture of Complexity, which incorporates inter, multi and transdisciplinarity, multiple intelligences, different learning and doings, resulting from the interaction among human cultures and local ecosystems, are mediated or guided by the ecological design. With a view to answer an intriguing question, among others, we reflect upon the feasibility of an architecture which formulates a habitable area as part of an ecosystem, which expands beyond itself and reverberates with the land which, in response, provides feedback to the constructed environment. Aimed at an answer we have developed Gaia Terranova, a theoretical-practical-experiential experiment in the South of Minas Gerais.
\end{abstract}

Keywords: Architecture, complexity, transdisciplinarity, Gaia Terranova. ecological design, sustainability.

\section{BIOFILIA, COMPLEXIDADE, INTER, MULTI E TRANSDISCIPLINARIDADE}

Seria possível uma arquitetura para além de si mesma, para além da forma, da beleza, da funcionalidade, das linhas retas, da circunscrição de espaços de utilidade humana apenas? Seria possível uma arquitetura que formulasse um espaço habitável como parte de um ecossistema, que se expandisse para além de si mesma e reverberasse com o terreno que, em sintonia retroalimentasse o ambiente construído? Seria possível uma casa concebida como uma célula, um ser vivo, parte de um tecido maior, como o terreno, a vizinhança e a microbacia hidrográfica na qual se insere? Seria possível uma arquitetura que explicitasse numa casa o nascer e por do sol, da 
lua, das estrelas e planetas, ensinando silenciosamente aos moradores seu lugar no espaço-tempo? Seria possível uma arquitetura que mostrasse o caminho da brisa soprando os distintos aromas da região e a direção dos ventos ora trazendo chuvas da Amazônia, ora do Atlântico, ou ainda o frio seco da Antártica? Seria possível uma arquitetura que ampliasse e fortalecesse a diversidade de vida ao invés de reduzi-la, ensinando ou resgatando em seus moradores que eles estão intimamente imersos numa imensa e magnífica sinfonia, que não estão sozinhos, que estão conectados não só entre si, mas com a casa, o terreno, a bacia hidrográfica, os animais e vegetais, os ecossistemas, os vales e montanhas, a biorregião, a biosfera e a cosmosfera? $\mathrm{E}$, se for possível uma arquitetura assim engendrada, como seria sua manifestação em uma casa de classe média, um prédio de escritórios, ou ainda uma vila, bairro, cidade? Como estabelecer uma arquitetura biofílica?

Por biofilia entendemos o amor e cuidado com tudo o que é vivo. Biofilia é amor à vida, e o novo -ismo que se propõe é o do Biocentrismo, colocando a Vida no mais elevado patamar, significando superior ao Humano (fruto e não senhor da evolução da vida) e suas criações.

O ser humano não é máquina, como quer a visão reducionista, mas um ser vivo, um organismo em relação e simbiose com seu planeta. Um ser vivo, de microrganismo a humano, nunca se apresenta fragmentado, é sempre um sistema complexo, composto por partes interconectadas e respondentes a ciclos, teias e redes, dotado da capacidade de replicação, ou autopoiese ${ }^{1}$ (MATURANA, 2001). Nossa sociedade apresenta características de crescente complexidade, não necessariamente mais viva, já que as partes que a compõe não se caracterizam pela incorporação ou reprodução de ciclos, teias e redes, ou de relações e comunicação entre as partes (que no entanto crescem vertiginosamente com as novas tecnologias de informação), mas ainda por processos dissociativos, excludentes, fragmentados e lineares, incapazes de dar respostas adequadas à crescente complexidade da sociedade planetária.

Esse tema, o da complexidade, tem despertado interesse em várias áreas do conhecimento. Nicolescu (1999), por exemplo, diz da complexidade que, sendo uma complexidade desordenada, seu conhecimento não faria sentido. Por outro lado, como apontam as teorias quânticas ou cosmológicas mais recentes, estamos diante de uma complexidade ordenada, de padrões até então não percebidos e mensurados, portadores de ordem e simplicidade de uma nova natureza, sendo este, justamente, o objeto de estudo e compreensão de um novo conhecimento, dito complexo. 
O termo complexidade, do latim complexus, significando o que é tecido em conjunto, tem em Edgar Morin talvez seu maior teórico, defensor e disseminador. A escola filosófica da complexidade, ao contrário da visão cartesiana de fracionar e reduzir para compreender, vê o mundo de forma indissociada, fruto de interações, alimentações, retroalimentações, processos e ligações que não podem ser compreendidos de maneira isolada. Para Morin (2002), o humano, como unidade complexa, é ao mesmo tempo biológico, social, afetivo e racional, assim como a sociedade é ao mesmo tempo histórica, econômica, sociológica, religiosa, etc. Unidades complexas são multidimensionais, formadas por texturas e interligações, tecidas em conjunto, que não podem ser compreendidas isoladamente, o que nos leva ao conhecimento pertinente, que reconhece este caráter multidimensional e busca integrar não apenas as partes entre si, mas também as partes e o todo. A noite escura se torna clara com o despontar da lua, assim como o dia claro escurece com a passagem das nuvens. O Yin e o Yang chineses que se mesclam formando o Tao. Não há escolha a ser feita entre um e outro, apenas o entendimento de que ambos compõem uma unidade maior.

Uma Ciência feita de partes quebradas, desconectadas, isoladas, feita de padrões rompidos, de reduções e simplificações perigosas leva à cegueira paradigmática, excluindo opostos complementares, complexos, como sujeito/objeto, alma/corpo, matéria/espírito, qualidade/quantidade, sentimento/razão, liberdade/determinismo, existência/essência (MORIN, 2002). As Ciências Exatas, herdeiras de Newton, Descartes, Bacon e tantos outros, querendo compreender e explicar o mundo reduzindo a complexidade do cotidiano a meros componentes estáticos, controláveis, mensuráveis com régua e compasso, conectados por processos meramente mecânicos, se de um lado contribuiram para grande avanço em todas as áreas do conhecimento, por outro nos têm levado aos limites desta forma de pensar-ser-estar no mundo. Posto que, a pessoa/sociedade formada, informada, conformada e deformada pelo pensamentovisão das partes, da extremada especialização, deixa de perceber o todo, o complexo, as interligações e conexões, as contradições, delírios e superações da exuberante explosão de vida que nos inunda a todos, todos os dias, há quase 4 bilhões de anos.

A matemática clássica e a geometria euclidiana, lidando com quantidades e fórmulas, não têm como representar sistemas dinâmicos, sistemas vivos, sistemas complexos que incorporam e descrevem qualidades e padrões, como o redemoinho num corpo aquoso ou cone de vento, interligando-os ao movimento e estrutura de galáxias espiraladas como a Via Lactea; ou ainda descrever uma nuvem, relâmpago ou delta de um rio; ou ainda a folha de uma samambaia e sua relação com a floresta. Para a 
descrição de estruturas complexas presentes na natureza, uma nova matemática e geometria se fizeram necessárias. Assim, em 1975 Mandelbrot cunhou a expressão "fractal" (do latim fractus, quebrado) para identificar uma nova geometria, não-euclidiana, capaz de representar fenômenos e estruturas complexas, a geometria fractal².

Uma propriedade fundamental do fractal é que seus padrões característicos são encontrados em diversos níveis, de modo que qualquer parte, em qualquer escala, guarda semelhança com o todo, ao que se chama autossimilaridade. Capra (2006) dá vários exemplos de autossimilaridade na natureza: rochas em montanhas se assemelham a montanhas; ramificações de relâmpagos ou nuvens que se repetem várias vezes; linhas litorâneas que reproduzem em diferentes escalas as praias, baias e promontórios; ramos de árvores e vasos sanguíneos que guardam similaridade entre si, apontando para padrões primários, subjacentes às estruturas, seja nos níveis micro, meso ou macrocósmico, como mostra a Figura 1.
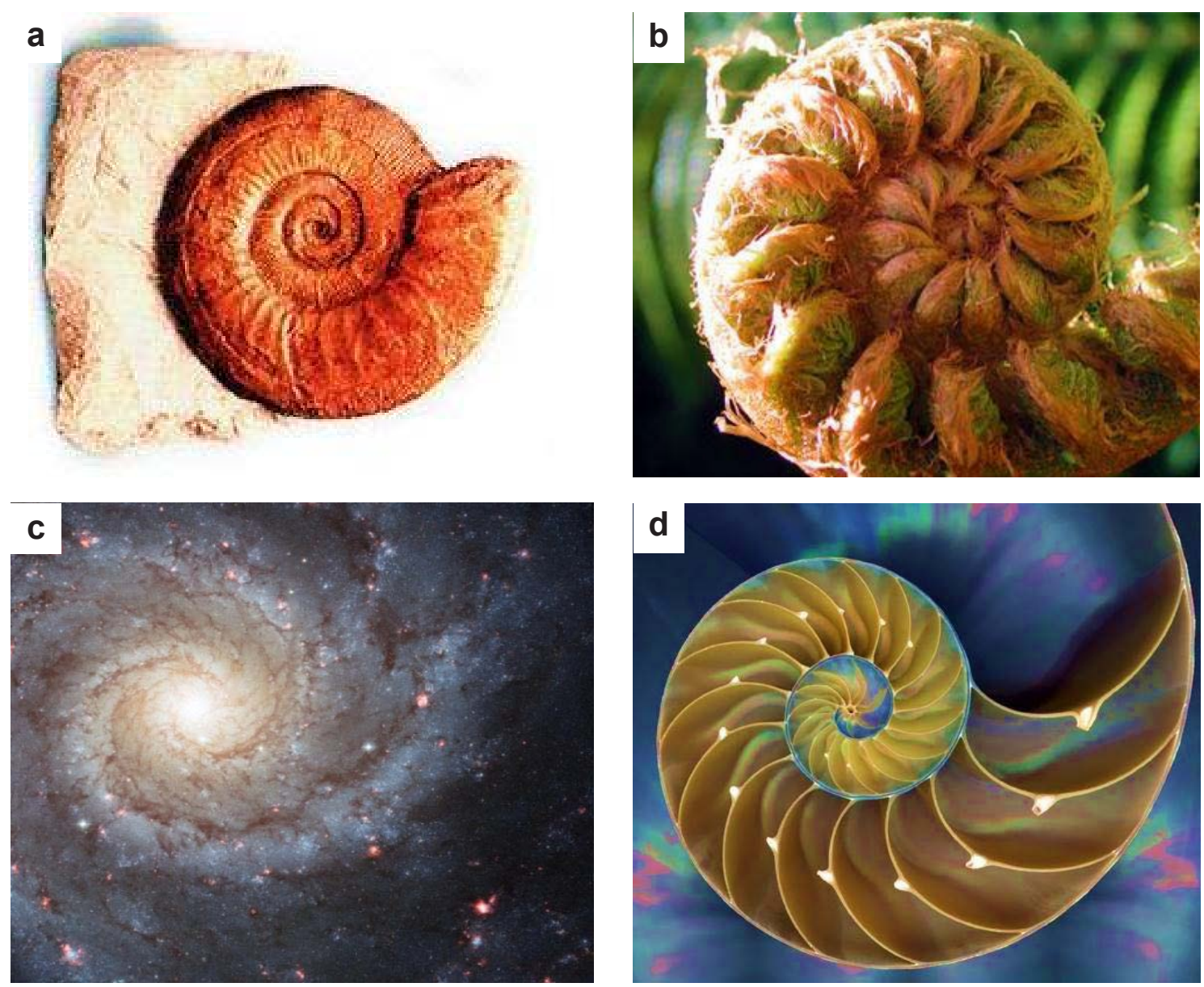

Figura 1: Exemplos de autossimilaridade na Natureza (a. Amonite (fóssil), b. Broto de samambaia, c. Galáxia M743) e sua representação por um fractal (d. Nautilus (representação fractal)). 
O modelo cartesiano de fracionar os fenômenos na tentativa de compreendê-los e explicá-los, originou uma miríade de disciplinas, desdobrando-se em outras tantas com a especialização crescente, fracionando cada vez mais o entendimento dos objetos de estudo ao tempo que gera imensas quantidades de informação. A necessidade de manter-se algum contato entre as disciplinas originou, em meados do século $\mathrm{XX}$, a pluri e interdisciplinaridade. A pluridisciplinaridade, ou multidisciplinaridade, sendo o estudo de um objeto de uma dada disciplina por várias disciplinas ao mesmo tempo, mantém a estrutura da pesquisa disciplinar, embora agora enriquecida por diferentes visões, como um quadro, uma obra de arte, sendo estudada por disciplinas como ótica, história da arte, história das religiões, química, física, etc. Já a interdisciplinaridade transfere métodos de uma disciplina para outra, originando novos campos de aplicação e/ou estudos, distinguindo-se três diferentes graus, explicados por exemplos: (a) aplicação - transferência dos métodos da física nuclear para a medicina, originando novos tratamentos para o câncer; (b) epistemológico - métodos da lógica formal aplicados ao direito produzindo análises na epistemologia do direito; (c) criação de novas disciplinas - matemática aplicada a fenômenos meteorológicos ou bolsa de valores originando a teoria do caos. Em cada um dos diferentes graus, a interdisciplinaridade permanece atrelada à pesquisa disciplinar, podendo gerar novas e mais especializadas disciplinas. A transdisciplinaridade, por sua vez, está ao mesmo tempo entre as disciplinas, através das disciplinas e além das disciplinas, tendo por objetivo a compreensão do mundo presente, buscando a unidade do conhecimento. Se a pesquisa disciplinar envolve, não raro, fragmentos de um único nível de Realidade ${ }^{4}$, a transdisciplinaridade se interessa pela ação simultânea de diversos níveis de Realidade (NICOLESCU, 1999). Segue que a visão transdisciplinar propõe considerar a Realidade como multidimensional, estruturada em múltiplos níveis, substituindo a visão clássica de uma Realidade unidimensional, com um único nível de manifestação. Se a lógica clássica mantém separados e mutuamente excludentes os opostos aparentes, a lógica do Terceiro Incluído ${ }^{5}$ os unifica em novo nível de realidade, que por sua vez passa a fazer parte de nova dualidade que se unificará em novo nível de realidade e assim por diante. A Figura 2 exemplifica essa evolução. No Nível de Realidade 1, os contraditórios A e Não-A estão presentes e não podem se conciliar, o que ocorre no Nível de Realidade 2, por meio do terceiro termo T, que inclui os contraditórios do nível anterior em não contraditórios nesse nível. Por outro lado, no Nível 2, o termo T pode se transformar em um novo contraditório ( $A^{\prime}$ ) para esse nível de Realidade, oposto ao Não-A'. Essa nova contradição, se não pode ser resolvida nesse nível de Realidade, o é no Nível de Realidade 3, onde A' e Não-A' são incluídos por T' e assim por diante, seguindo por infinitos níveis de Realidade. 
Nível de

Realidade 3

Nível de

Realidade 2

Nível de Realidade 1

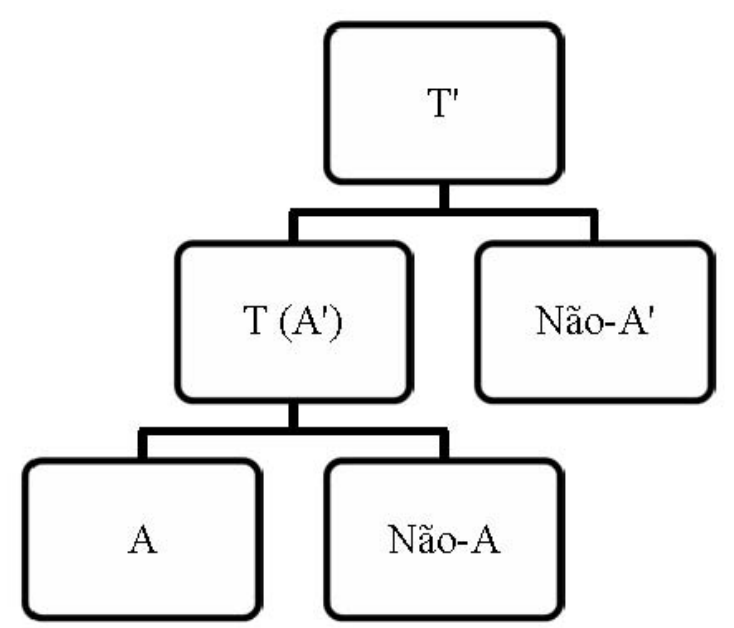

Figura 2: Níveis de Realidade e par de contraditórios.

A metodologia da pesquisa transdisciplinar se assenta sobre três pilares: (a) os níveis de Realidade; (b) a lógica do terceiro incluído; e (c) a complexidade, sendo a disciplinaridade, multidisciplinaridade, interdisciplinaridade e transdisciplinaridade, as quatro flechas de um mesmo arco, o do conhecimento (NICOLESCU, 1999, p. 48). Morin (2003) acrescenta que essa nova abordagem do conhecimento exige uma reforma do pensamento que, por sua vez, exige uma reforma da Universidade: Falo de uma reforma que leve em conta nossa aptidão para organizar o conhecimento - ou seja, pensar (MORIN, 2003, p. 83). O pensamento complexo incorpora e extrapola o pensamento linear, cartesiano, próprio para a descrição de sistemas simplificados, mas não suficiente para lidar com questões mais complexas. Segue Morin (2003) considerando que, sobre o papel da Universidade, esta tem a função de: (a) ritualizar uma herança cultural de valores, saberes e ideias que permitem conservar, memorizar, integrar os conhecimentos; (b) regenerar esta herança ao fazer sua releitura constante, atualizando-a e transmitindo-a; e (c) gerar novos saberes, ideias e valores que farão parte da herança comum futura. Dessa forma, a Universidade é ao mesmo tempo conservadora, regeneradora e geradora de novos conhecimentos, devendo adaptarse às necessidades da sociedade contemporânea ao mesmo tempo em que mantém viva sua missão transecular de conservar, transmitir e enriquecer o patrimônio cultural universal.

Essa reforma do pensamento e do processo educativo encontra ecos em diferentes trabalhos, além dos de Morin, com diferentes enfoques mostrando horizontes novos para a educação, ciência e tecnologia, como aqueles de Gardner (1995) e colegas da Universidade de Harvard que propõem as Múltiplas Inteligências e Goleman (1996), 
propondo a Inteligência Emocional e, mais recentemente, a Inteligência Ecológica.

Assim se desdobram essas inteligências:

Lógico-matemática - capacidade de confrontar e avaliar objetos e abstrações, discernindo as suas relações e princípios subjacentes. Matemáticos, cientistas e filósofos como Henri Poincaré, Albert Einstein, Marie Curie, dentre outros, apresentam essas características.

Linguística - caracteriza-se por um domínio e gosto especial pelos idiomas, palavras e escrita. Predomina em poetas, escritores e linguistas, como T. S. Eliot, Jorge Amado e Guimarães Rosa.

Musical - habilidade para compor e executar padrões musicais, executando pedaços de ouvido, em termos de ritmo e timbre, mas também escutando-os e discernindo-os. Pode estar associada a outras inteligências, como a lingüística, espacial ou cinestésico-corporal. É predominante em compositores, maestros, músicos, críticos de música como por exemplo, Ludwig van Beethoven, Caetano Veloso e Phillip Glass.

Espacial - capacidade de compreender o mundo visual com precisão, permitindo transformar, modificar percepções e recriar experiências visuais até mesmo sem estímulos físicos. Predomina em arquitetos, artistas, escultores, cartógrafos, navegadores e jogadores de xadrez, como Michelangelo, Garry Kasparov e Milton Santos.

Cinestésico-corporal - capacidade de controlar e orquestrar movimentos do corpo. É predominante entre atores e aqueles que praticam a dança ou esportes: Pelé, Garrincha, Ana Botafogo.

Intrapessoal - capacidade de se conhecer, estando mais desenvolvida em escritores, psicoterapeutas, conselheiros, místicos e espiritualistas como Karl Gustav Jung, São Francisco, Dalai Lama.

Interpessoal - habilidade de entender as intenções, motivações e desejos dos outros. Encontra-se mais desenvolvida em políticos, religiosos, comunicadores e professores, como Mahatma Gandhi, Chacrinha e Lula. 
Posteriormente ${ }^{6}$, essas sete inteligências foram acrescidas de outras duas, embora a última ainda não estabelecida:

Naturalista - sensibilidade para compreender e organizar os objetos, fenômenos e padrões da natureza, como reconhecer e classificar plantas, animais, minerais, incluindo rochas e gramíneas e toda a variedade de fauna, flora, meio-ambiente e seus componentes. É característica de paisagistas, arquitetos, mateiros, botânicos. São exemplos deste tipo de inteligência Charles Darwin, Rachel Carson e Alexander von Humboldt.

Espiritual/Existencial - investigada no terreno ainda do "possível" e carecendo de maiores evidências. Abrange a capacidade de refletir e ponderar sobre questões fundamentais da existência e da transcendência. Seria característica de líderes espirituais e de pensadores filosóficos como Jean-Paul Sartre, Margaret Mead, Dalai Lama e Charles Darwin.

Desse amálgama de inteligências, saberes, formas, conteúdos, singularidades, pluralidades, conceitos, conhecimentos, teorias e práticas, emergem também novas formas de ver, olhar, ser, estar, viver e conviver no mundo. E com eles, novas abordagens para a Ciência e Tecnologia, como as propostas pela Engenharia Ecológica, a Permacultura e o Design Ecológico (SANGUINETTO, 2010), que dão conteúdo ao design e estudos em Gaia Terranova, e ainda o Desenho Ambiental, proposto e fomentado por Franco (2008).

De todos os campos do saber e fazer chegam informações de mudanças de padrões, conceitos e atitudes. Aos poucos fica evidente a correção de Einstein quando afirmava que um problema não poderia ser resolvido com o mesmo estado mental que o criou. Os problemas criados ao adotarmos uma visão de mundo mecanicista, necessitam de novo estado mental que permita solucioná-los. Um terceiro termo T que apazigue os opostos aparentemente irreconciliáveis e que não será encontrado no mesmo nível de pensamento-ação que criou os problemas que se busca solucionar. Novas formas de ver, pensar, sentir, perceber, ser, estar e agir no mundo começam a emergir, trazendo consigo o novo e também o receio do erro, próprio de sistemas desconhecidos, não consolidados, insipientes. 


\section{UM ESTUDO DE CASO: GAIA TERRANOVA}

Gaia Terranova é nome fantasia para designar um conjunto de duas residências e seus terrenos, somando $2.400 \mathrm{~m}^{2}$, localizados na zona rural do município de Piranguinho, MG, biorregião ${ }^{7}$ da Serra da Mantiqueira. O espaço vem sendo utilizado pelo autor e sua família como moradia e Campo de Estudos, Pesquisas, Desenvolvimento e Práticas Sustentáveis. A Figura 3 mostra a localização de Gaia Terranova, em relação a cidades do Sul Mineiro.

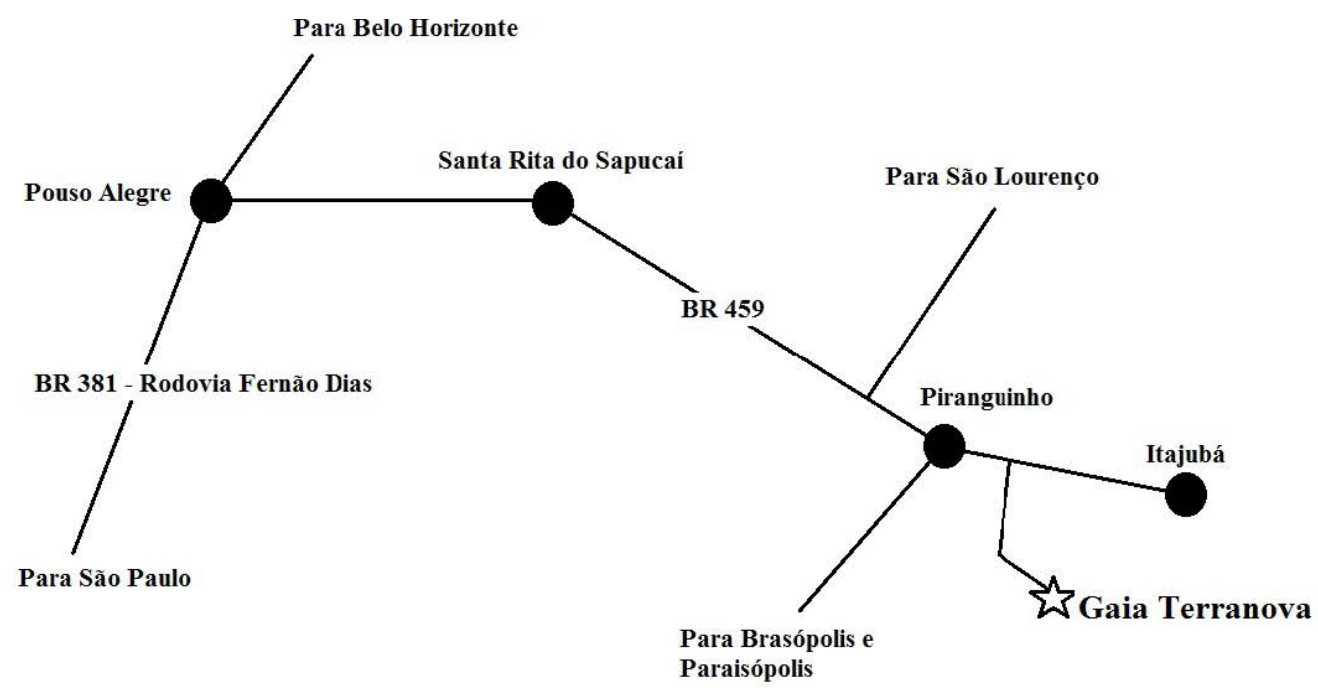

Figura 3: Localização de Gaia Terranova em relação a cidades do Sul de Minas Gerais (SANGUINETTO, 2010).

Gaia Terranova é um experimento teórico-prático-vivencial, tentando integrar de maneira orgânica arquitetura, design, engenharia, ecologia, agroecologia, biologia, filosofia e espiritualidade, conferindo um perfil inter, multi e transdisciplinar na concepção e construção de uma casa ecológica integrada a um habitat sustentável, mediados por tecnologias vivas de tratamento de resíduos domésticos e explicitados pela educação para a sustentabilidade. Esses campos de estudos e pesquisas foram conectados pelo design ecológico, que forneceu as bases para o planejamento, interligação e fechamento de ciclos e dos fluxos de matéria e energia, potencializando o estabelecimento de redes e teias de vida cada vez mais complexas. Ao conjunto visualizamos um eventual embrião de Arquitetura da Complexidade. 


\section{FRACTAL CONHECIMENTO-AÇÃO}

Esse experimento propõe reproduzir a complexidade dos sistemas vivos, tendo como elemento de ligação e reverberação entre casa e terreno, o que chamamos Tecnologias Vivas para o tratamento de efluentes e resíduos orgânicos domésticos, resgatando água e nutrientes na recuperação de solos degradados e produção de alimentos de base orgânica, potencializando a ampliação da biodiversidade local e incorporando a possibilidade de coevolução entre cultura e natureza. O método do experimento partiu de um padrão simples de construção de conhecimento-ação (Figura 4), que atua como um fractal que se vai amplificando e complexificando em diferentes níveis ou camadas, formando uma estrutura de conhecimento não-linear.

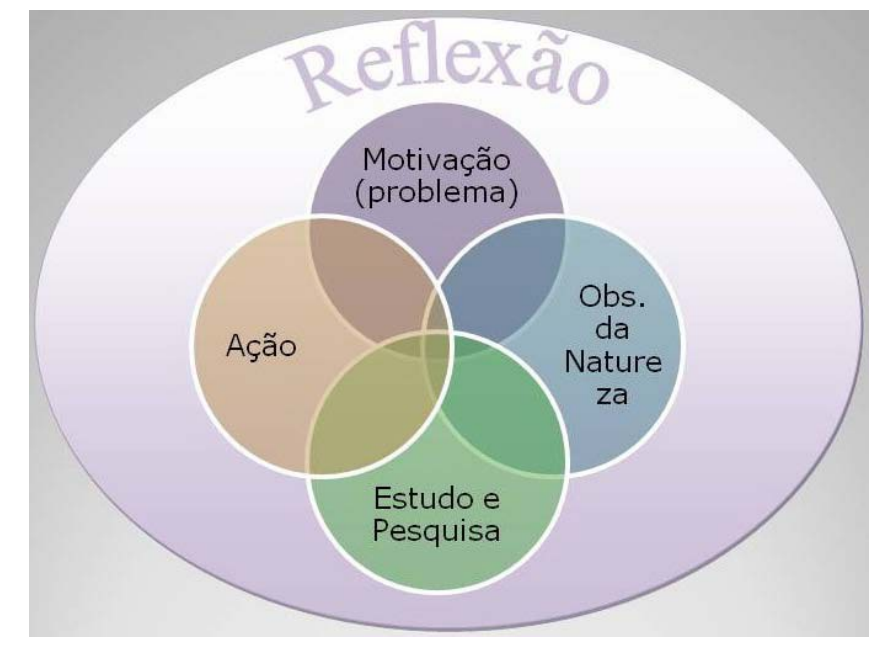

Figura 4. Fractal de conhecimento-ação.

Sempre permeado pela Reflexão, que relaciona constantemente os quatro componentes do fractal conhecimento-ação, interligados em rede e retroalimentados entre si, estabelece-se um moto contínuo que engloba:

1. Motivação (problema) - Como tratar biologicamente e reaproveitar água e nutrientes de esgotos residenciais?; ou: Como reproduzir os ciclos, teias e redes do ambiente natural no cotidiano de uma família de classe média, aproximando o conjunto casaterreno dos ecossistemas locais?;

2. Observação da Natureza - Observação do ambiente natural e dos processos vitais envolvidos na ciclagem de nutrientes, autodepuração dos corpos d'água e evolução de ecossistemas alterados - aprendizado direto, vivencial, mediado por processos intuitivos, sensitivos, artísticos, emocionais e espirituais - inteligências múltiplas; 
3. Estudo e pesquisa - Revisão de literatura, conhecimento acadêmico e técnicocientífico - aprendizado mediado pela razão;

4. Ação (solução) - Estágios sucessivos de ação-reflexão, buscando integrar os questionamentos, gerando novos desafios, questionamentos, observação, estudo e pesquisa e práticas renovadas, aproximando as soluções no cotidiano daquelas desenvolvidas e baseadas em padrões vivos, sustentáveis.

O fractal conhecimento-ação permeou e permeia toda experimentação em Gaia Terranova. Para entendermos sua operacionalização, a Tabela 1 apresenta sua utilização e desdobramentos, partindo do Design Ecológico até a implantação e validação das Tecnologias Vivas de tratamento de efluentes, apresentando reflexões sobre questões que nortearam todo processo e o resultado destas reflexões. A cada passo as relações vão-se complexificando, sendo muitas das vezes quase impossível caminhar linearmente e os limites entre teoria e prática, reflexão e ação, observação e estudo tornam-se tênues ao ponto de se dissolverem, conferindo um carácter transdisciplinar ao trabalho. Raciocínio idêntico permeou o processo de concepção, design, planejamento e construção da casa ecológica e implantação do habitat sustentável.

Tabela 1: Fractal conhecimento-ação complexificado nas Tecnologias Vivas de tratamento de águas cinzas e pretas.

\begin{tabular}{|c|c|c|}
\hline \multicolumn{3}{|c|}{ I - Design Ecológico } \\
\hline $\begin{array}{l}\text { Fractal } \\
\text { metodológico }\end{array}$ & Reflexão & Resultado \\
\hline Motivação & $\begin{array}{l}\text { Problema: Como tratar } \\
\text { biologicamente e reaproveitar } \\
\text { água e nutrientes de esgotos } \\
\text { residenciais? }\end{array}$ & \\
\hline $\begin{array}{l}\text { Observação da } \\
\text { Natureza }\end{array}$ & $\begin{array}{l}\text { Como se dá o tratamento e } \\
\text { purificação da água no ambiente } \\
\text { natural? }\end{array}$ & $\begin{array}{l}\text { Experiência pessoal do } \\
\text { autor. } \\
\text { Vivência no ambiente } \\
\text { natural. }\end{array}$ \\
\hline $\begin{array}{l}\text { Estudo e } \\
\text { Pesquisa }\end{array}$ & $\begin{array}{l}\text { O que propõe a literatura técnico- } \\
\text { científica e de base permacultural } \\
\text { para esses casos? }\end{array}$ & $\begin{array}{l}\text { Permacultura, Prosab, } \\
\text { ABNT, Elsevier, etc. }\end{array}$ \\
\hline Ação & $\begin{array}{l}\text { Como desenvolver uma } \\
\text { tecnologia ambientalmente } \\
\text { amigável (ecotecnologia) para o } \\
\text { tratamento de águas cinzas? }\end{array}$ & $\begin{array}{l}\text { Solução: implantação de } \\
\text { sistema piloto de } \\
\text { banhado construído } \\
\text { (wetland). }\end{array}$ \\
\hline
\end{tabular}




\begin{tabular}{|c|c|c|}
\hline \multicolumn{3}{|l|}{ II - Concepção } \\
\hline $\begin{array}{l}\text { Fractal } \\
\text { metodológico }\end{array}$ & Reflexão & Resultado \\
\hline Motivação & $\begin{array}{l}\text { Como construir um } \\
\text { sistema de baixo custo e } \\
\text { fácil replicação tratando } \\
\text { diferentemente águas } \\
\text { pretas e cinzas? }\end{array}$ & $\begin{array}{l}\text { Recepção de águas cinzas } \\
\text { provenientes do atendimento de } \\
4 \text { a } 5 \text { pessoas. } \\
\text { Reaproveitamento de materiais } \\
\text { de construção. } \\
\text { Coleta de plantas e solo de } \\
\text { banhados locais. } \\
\text { Plantio das espécies. }\end{array}$ \\
\hline $\begin{array}{l}\text { Observação da } \\
\text { Natureza }\end{array}$ & $\begin{array}{l}\text { Como o sistema } \\
\text { implantado responde à } \\
\text { demanda? }\end{array}$ & $\begin{array}{l}\text { Observação: } \\
\text { Visual e olfativa: evolução, } \\
\text { odores, composição floral; } \\
\text { Biodiversidade: atração de } \\
\text { pássaros, borboletas, abelhas, } \\
\text { vermes; } \\
\text { Cultural: aceitação da } \\
\text { ecotecnologia; } \\
\text { Estética: paisagismo. }\end{array}$ \\
\hline $\begin{array}{l}\text { Estudo e } \\
\text { Pesquisa }\end{array}$ & $\begin{array}{l}\text { O que propõe a literatura } \\
\text { técnico-científica e de } \\
\text { base permacultural para } \\
\text { esses casos? }\end{array}$ & $\begin{array}{l}\text { Permacultura, Prosab, ABNT, } \\
\text { Elsevier, etc. }\end{array}$ \\
\hline \multirow[t]{4}{*}{ Ação } & Intervenções no sistema & Aperfeiçoamento do banhado. \\
\hline & Manutenção & $\begin{array}{l}\text { Podas e reutilização das plantas } \\
\text { para compostagem. }\end{array}$ \\
\hline & Custos & $\begin{array}{l}\text { Levantamento dos custos de } \\
\text { construção e manutenção. }\end{array}$ \\
\hline & Aprendizado prático & $\begin{array}{l}\text { Funcionamento adequado da } \\
\text { ecotecnologia. }\end{array}$ \\
\hline
\end{tabular}




\begin{tabular}{|c|c|c|}
\hline \multicolumn{3}{|c|}{ III - Tecnologia Viva } \\
\hline $\begin{array}{l}\text { Fractal } \\
\text { metodológico }\end{array}$ & Reflexão & Resultado \\
\hline Motivação & $\begin{array}{l}\text { Como desenhar, } \\
\text { dimensionar e } \\
\text { projetar Tecnologias } \\
\text { Vivas para o } \\
\text { tratamento das águas } \\
\text { cinzas e águas pretas } \\
\text { em sistemas } \\
\text { independentes, tendo } \\
\text { por base os } \\
\text { aprendizados com o } \\
\text { sistema piloto? }\end{array}$ & $\begin{array}{l}\text { Design de sistemas para o tratamento } \\
\text { de águas cinzas e pretas a partir do } \\
\text { aprendizado com o banhado piloto. }\end{array}$ \\
\hline $\begin{array}{l}\text { Observação } \\
\text { da Natureza }\end{array}$ & $\begin{array}{l}\text { Como se daria o fluxo } \\
\text { do efluente e sua } \\
\text { relação com os } \\
\text { componentes bióticos } \\
\text { e abióticos dos } \\
\text { sistemas? } \\
\text { Como o sistema } \\
\text { evolui ao longo do } \\
\text { tempo? }\end{array}$ & $\begin{array}{l}\text { Planejamento dos sistemas. } \\
\text { Sensorial: visual, olfativa. } \\
\text { Biodiversidade: atração de pássaros, } \\
\text { anfíbios e insetos; criação de peixes } \\
\text { (tilápia); colonização por plantas não } \\
\text { existentes nos arredores. } \\
\text { Cultural: aceitação das tecnologias } \\
\text { vivas. } \\
\text { Estética: paisagismo. }\end{array}$ \\
\hline $\begin{array}{l}\text { Revisão de } \\
\text { literatura }\end{array}$ & $\begin{array}{l}\text { O que propõe a } \\
\text { literatura técnico- } \\
\text { cientifica? }\end{array}$ & $\begin{array}{l}\text { Teoria orientando a prática (Elsevier, } \\
\text { Prosab, ABNT, Permacultura, } \\
\text { Biomimética, Autopoiese). }\end{array}$ \\
\hline \multirow[t]{6}{*}{ Ação } & Dimensionamento & $\begin{array}{l}\text { Sistema de tratamento de águas cinzas } \\
\text { e águas pretas para } 4 \text { pessoas. }\end{array}$ \\
\hline & Implantação & $\begin{array}{l}\text { Sistema de águas cinzas: filtro, } \\
\text { banhado e lagoas multifuncionais } \\
\text { (várias versões). } \\
\text { Sistema de águas pretas: decanto- } \\
\text { digestor, filtro biológico, banhado } \\
\text { construido, vala de infiltração, linha de } \\
\text { bananeiras. }\end{array}$ \\
\hline & Utilização & Recepção de efluentes de 3 pessoas. \\
\hline & Intervenção & $\begin{array}{l}\text { Aperfeiçoamento do sistema de } \\
\text { tratamento de águas cinzas (versão } \\
\text { 03). }\end{array}$ \\
\hline & Manutenção & $\begin{array}{l}\text { Podas e reutilização das plantas para } \\
\text { compostagem. }\end{array}$ \\
\hline & Custos & $\begin{array}{l}\text { Levantamento dos custos de } \\
\text { construção e manutenção. }\end{array}$ \\
\hline
\end{tabular}




\begin{tabular}{|c|c|c|}
\hline \multicolumn{3}{|c|}{ IV - Desempenho operacional } \\
\hline $\begin{array}{l}\text { Fractal } \\
\text { metodológico }\end{array}$ & Reflexão & Resultado \\
\hline Motivação & $\begin{array}{l}\text { Os sistemas atendem } \\
\text { à legislação mais } \\
\text { restritiva de } \\
\text { lançamento de } \\
\text { efluentes? Como } \\
\text { validar os resultados } \\
\text { das análises? }\end{array}$ & $\begin{array}{l}\text { Definição de parâmetros físicos, } \\
\text { químicos e biológicos para análise. } \\
\text { Planejamento estatístico. }\end{array}$ \\
\hline $\begin{array}{l}\text { Observação da } \\
\text { Natureza }\end{array}$ & $\begin{array}{l}\text { Como plantas e } \\
\text { (micro)organismos se } \\
\text { relacionam e evoluem } \\
\text { nos sistemas? }\end{array}$ & $\begin{array}{l}\text { Crescimento de plantas e raízes e } \\
\text { relações com o funcionamento dos } \\
\text { sistemas, produção de biomassa, } \\
\text { ampliação da biodiversidade com a } \\
\text { chegada (sem intervenção humana } \\
\text { consciente) de novas espécies } \\
\text { vegetais, visita de animais, etc. }\end{array}$ \\
\hline $\begin{array}{l}\text { Revisão de } \\
\text { literatura }\end{array}$ & $\begin{array}{l}\text { Legislação ambiental, } \\
\text { artigos científicos }\end{array}$ & COPAM-CERH, CONAMA, ABNT. \\
\hline \multirow[t]{2}{*}{ Ação } & $\begin{array}{l}\text { Coleta de efluentes e } \\
\text { medição de volumes }\end{array}$ & $\begin{array}{l}\text { Coleta de amostras (compostas para } \\
\text { águas pretas) para análise. }\end{array}$ \\
\hline & Análises laboratoriais & $\begin{array}{l}\text { Sólidos. } \mathrm{DQO} . \mathrm{pH} \text {, condutividade. } \\
\text { alcalinidade, turbidez, OD, } \\
\text { coliformes. }\end{array}$ \\
\hline
\end{tabular}




\begin{tabular}{|c|c|c|}
\hline \multicolumn{3}{|l|}{ V - Validação } \\
\hline $\begin{array}{l}\text { Fractal } \\
\text { metodológico }\end{array}$ & Reflexão & Resultado \\
\hline Motivação & $\begin{array}{l}\text { Os resultados laboratoriais } \\
\text { das tecnologias vivas } \\
\text { confirmam a expectativa } \\
\text { de sustentabilidade? }\end{array}$ & $\begin{array}{l}\text { Comparação dos resultados das } \\
\text { análises laboratoriais e restrições } \\
\text { legais. }\end{array}$ \\
\hline $\begin{array}{l}\text { Observação } \\
\text { da Natureza }\end{array}$ & $\begin{array}{l}\text { Existem diferenças } \\
\text { visíveis, quantitativas e } \\
\text { qualitativas entre áreas do } \\
\text { terreno que receberam ou } \\
\text { não os efluentes tratados? }\end{array}$ & $\begin{array}{l}\text { Evolução de linha de bananeiras } \\
\text { que receberam ou não os } \\
\text { efluentes tratados (análise } \\
\text { estatística). } \\
\text { Percepção da evolução biológica } \\
\text { junto aos sistemas implantados. }\end{array}$ \\
\hline $\begin{array}{l}\text { Revisão de } \\
\text { literatura }\end{array}$ & $\begin{array}{l}\text { Sistemas domiciliares e/ou } \\
\text { permaculturais publicados. }\end{array}$ & $\begin{array}{l}\text { Comparação entre diferentes } \\
\text { sistemas. }\end{array}$ \\
\hline \multirow[t]{3}{*}{ Ação } & $\begin{array}{l}\text { Análise estatística e } \\
\text { discussão dos resultados } \\
\text { do monitoramento das } \\
\text { tecnologias vivas. }\end{array}$ & $\begin{array}{l}\text { Comparação em relação à } \\
\text { legislação federal e mineira, } \\
\text { ABNT e outros sistemas. }\end{array}$ \\
\hline & $\begin{array}{l}\text { Análise de custos e } \\
\text { retorno sobre o } \\
\text { investimento. }\end{array}$ & $\begin{array}{l}\text { Viabilidade das tecnologias vivas } \\
\text { em termos financeiros } \\
\text { (orçamento do empreendimento). }\end{array}$ \\
\hline & $\begin{array}{l}\text { As tecnologias vivas se } \\
\text { apresentam como } \\
\text { alternativas sustentáveis } \\
\text { para o tratamento } \\
\text { domiciliar de águas cinzas } \\
\text { e pretas? }\end{array}$ & Resultado final do trabalho. \\
\hline
\end{tabular}




\section{RESULTADOS}

O que estamos caracterizando talvez como um embrião de Arquitetura da Complexidade em Gaia Terranova, tem início com o Design Ecológico, aqui utilizado como ferramenta de desenho, planejamento e projeto, permitindo entendimento, estabelecimento e tecitura de fluxos, ciclos, redes e processos que se auto-fortalecem, gerando diversidade e abundância e integrando o humano e o natural de maneira mais equilibrada, harmônica e sustentável.

Seguindo princípio do Design Ecológico que propõe que as soluções emergem do local em que se se planeja um dado empreendimento, espera-se que diferentes locais apresentem diferentes condições e especificidades. $O$ estudo dessas condições e especificidades incorporaram no experimento conhecimentos como: a direção predominte dos ventos e brisas; a direção predominante das chuvas e tempestades; a insolação no verão e inverno; a posição do terreno em relação ao norte geográfico e bacia hidrográfica; os cursos d'água e caminhos de drenagem; a posição da casa em relação ao terreno; a vegetação do terreno e bacia hidrográfica; os ecossistemas locais; estradas e acessos; fontes energéticas e de água; o uso e ocupação do solo na bacia; plantações locais; a disponibilidade e diversidade de materiais construtivos locais; qualificação de mão de obra; impactos ambientais do empreendimento; fontes de água e energia; infra-estrutura de transportes, comunicações, acessos; costumes e tecnicas construtivas locais (Figuras 5, 6 e 7 ).

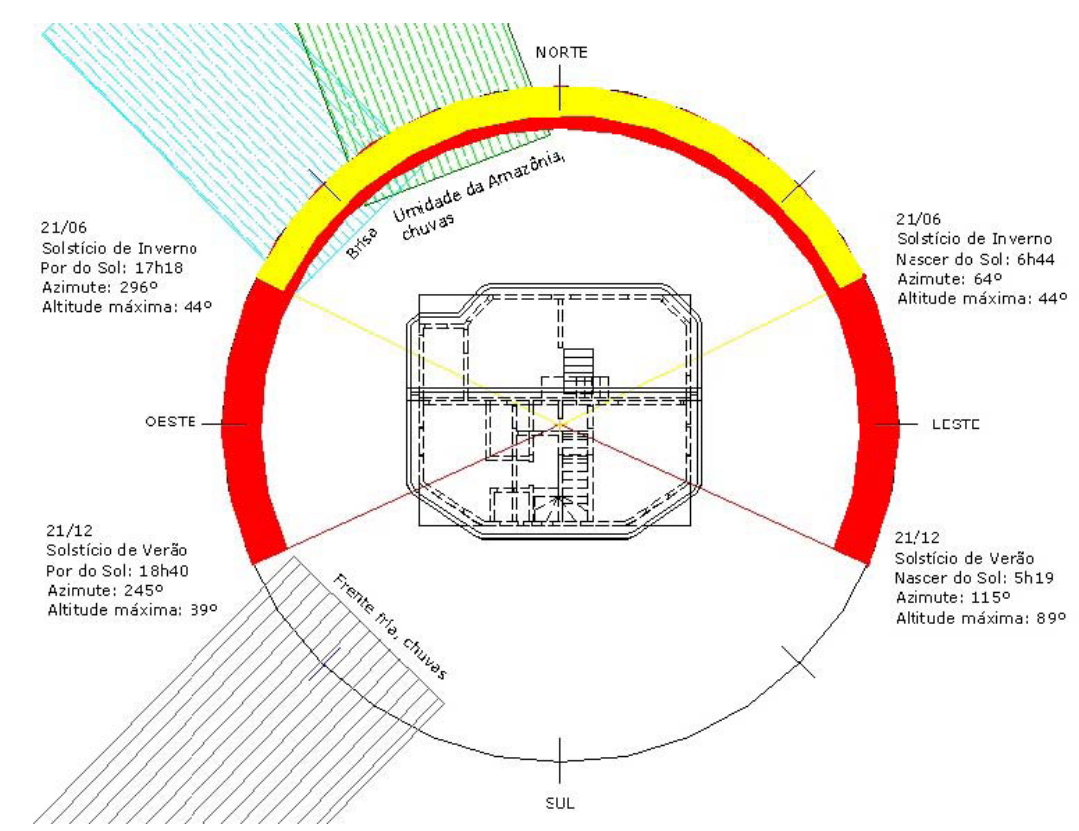

Figura 5: Estudo de influências abióticas no planejamento das residências. 

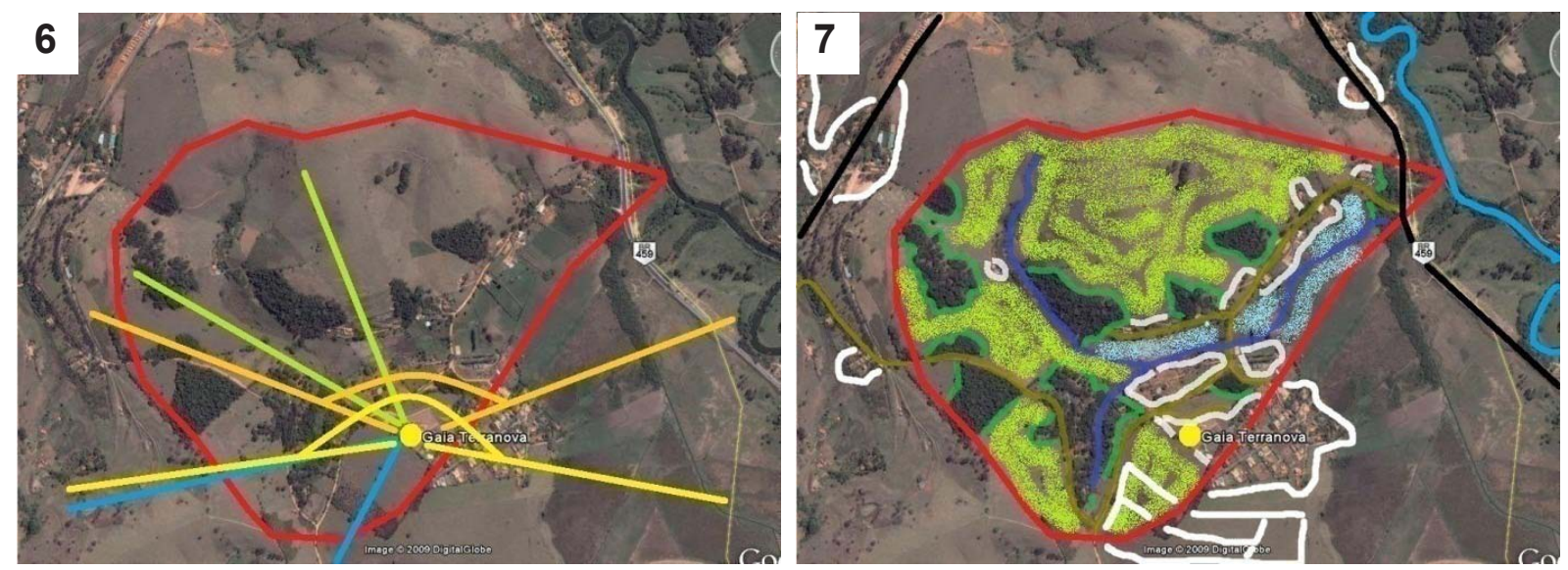

Figura 6: Estudo de relações entre casa e bacia hidrográfica.

Figura 7: Estudo de elementos naturais e construídos na bacia hidrográfica.

Com base nessas informações foi proposto um design de integração entre residência, terreno e bacia hidrográfica, orientando de um lado os fluxos de matéria e energia e estabelecendo ou reforçando ciclos e redes de água e nutrientes que potencializam a ampliação da biodiversidade local (Figura 8); e, de outro lado, favorecendo que os residentes usufruam de uma qualidade de vida ampliada e em sintonia com a vida ao redor, impactando de maneira positiva tanto os ecossistemas locais como a bacia hidrográfica em que se inserem.

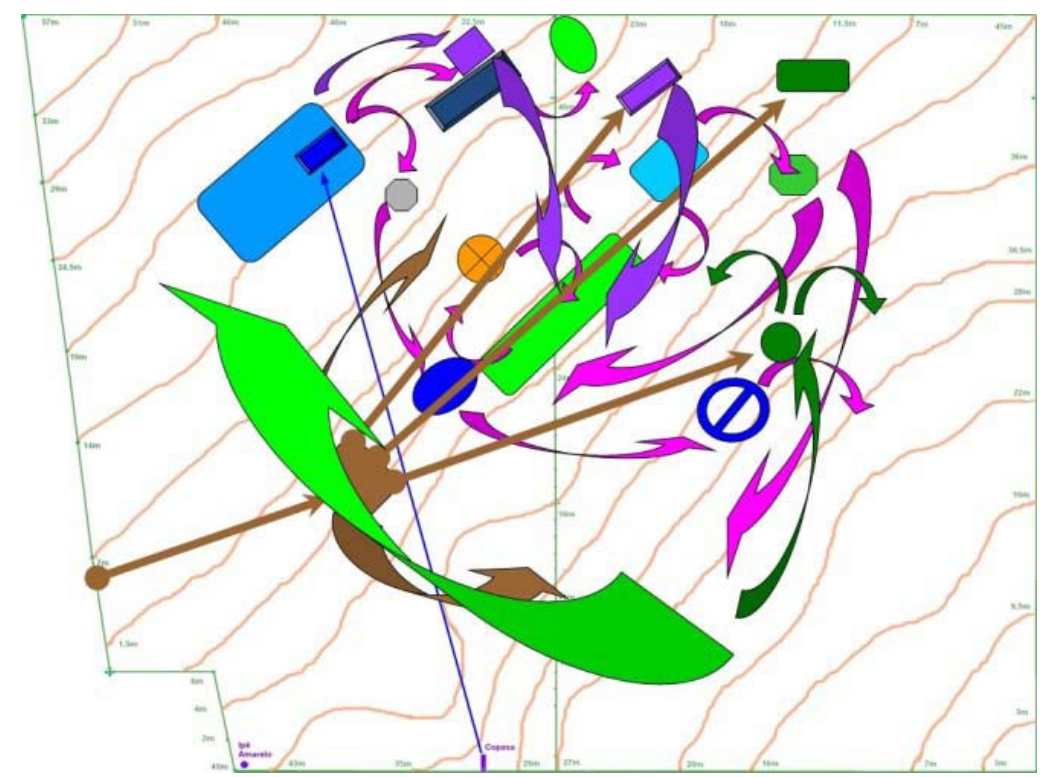

Figura 8: Estabelecimento de fluxos, ciclos e redes entre casa, terreno e tecnologias vivas (SANGUINETTO, 2010).

As Casas Ecológicas (Figura 9) foram construídas (uma ainda em construção) incorporando elementos, conhecimentos e processos de gestão zero de resíduos; tratamento 
biológico de efluentes com reúso das águas; captação, reservação e utilização de água de chuva; eficiência energética; bioconstrução; iluminação passiva; recuperação e reutilização de materiais diversos (madeiramento, vitrôs, portas, janelas, cerâmicas, etc); agroecologia no manejo do solo e implantação de pequeno sistema agroflorestal; produção orgânica de alimentos; reaproveitamento de resíduos orgânicos por meio da compostagem e minhocultura; recuperação de solos degradados; avaliação de impactos ambientais no uso e ocupação do solo; planejamento estratégico utilizando sistemas de informação geográfica; resgate de técnicas construtivas tradicionais e estudo de viabilidade técnica, econômica e ambiental. O design ecológico forneceu elementos para o projeto da residência, como: quadrante de chuvas, direção predominante das brisas, posição no terreno, insolação e caminhos aparentes do Sol ao longo das estações.

O terreno (Figura 10) foi organizado segundo o design ecológico e foi trabalhado segundo conceitos da permacultura e agroecologia, formando Habitats Sustentáveis, caracterizados por curvas de nivel, bacias de contenção, ilhas de vegetação (período inicial) e vários microecossistemas construídos, que vem ampliando e fortalecendo a biodiversidade local e auxiliando na recuperação de solos degradados, recarga de lençol freático, produção de alimentos, fortalecimento da agricultura familiar e mudanças de padrões e comportamentos locais em relação ao uso, ocupação e gestão do solo.

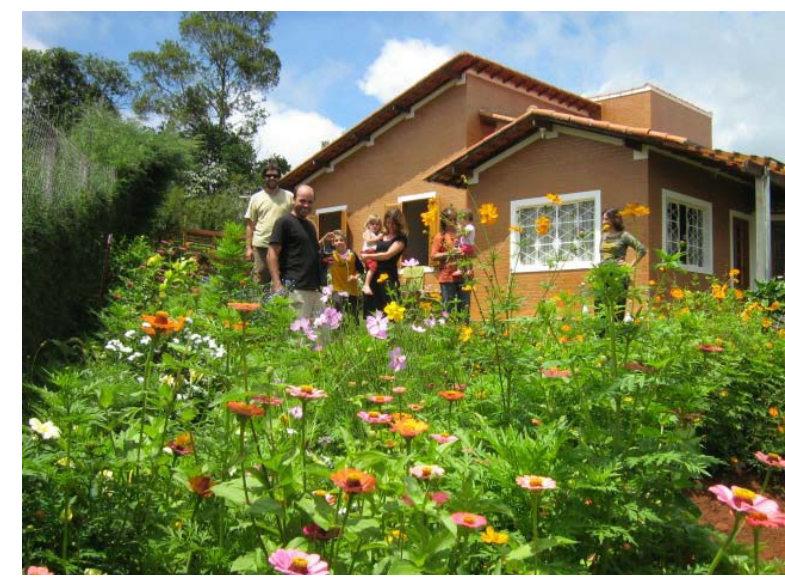

Figura 9: Casa Ecológica

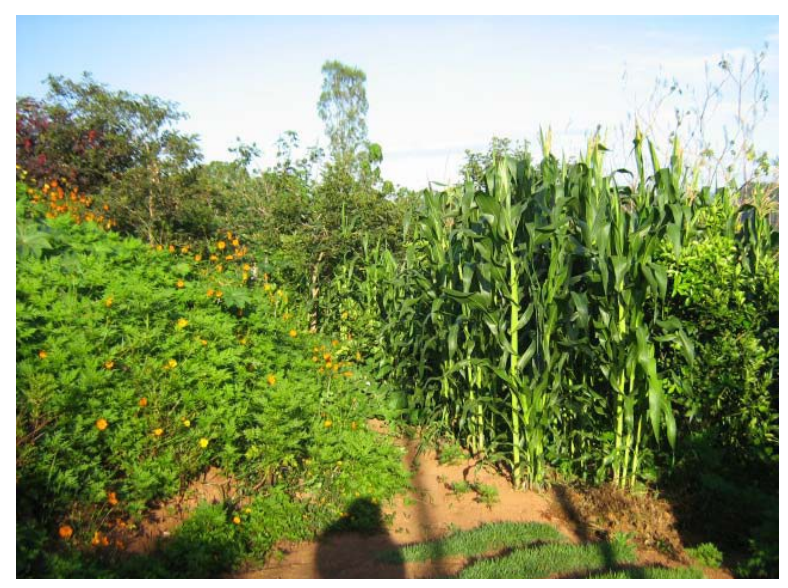

Figura 10: Habitat Sustentável.

$\mathrm{Na}$ interface entre as Casas Ecológicas e Habitats Sustentáveis, as Tecnologias Vivas de tratamento biológico de efluentes permitindo o reúso das águas, tendo por base o design ecológico, a permacultura e a engenharia ecológica, promovem a relação e interação entre terrenos e casas, fechando ciclos de reaproveitamento de resíduos 
orgânicos oriundos da cozinha (folhas, talos, cascas, etc) por meio da compostagem e tratamento e reúso de águas residuárias na produção de alimentos de base orgânica. As águas residuárias (esgotos) tratados são portadores de água e nutrientes, utilizados por plantas e microrganismos em seu processo de crescimento, via fotossíntese, mecanismo desenvolvido pela evolução para transformar energia solar em energia química. O manejo periódico dessa biomassa, por meio de podas e compostagem, disponibiliza nutrientes e energia para o sistema, seguindo para as hortas e pomar, ampliando a produção de alimentos de base orgânica (sem utilização de venenos ou adubos químicos). Os alimentos assim produzidos são consumidos pelos moradores e o ciclo se fecha, com a produção de novos resíduos e efluentes (Figura 11). Ao mesmo tempo, a energia cinética das águas de chuva é absorvida no sistema: (a) pela vegetação; (b) pela cobertura morta mantida como proteção para o solo; (c) por curvas de nível e bacias de contenção, instaladas em todo terreno de modo e impedir a erosão e carreamento de nutrientes ao mesmo tempo em que facilitam a infiltração, contribuindo para a recarga de lençois freáticos e minimização de eventuais enchentes e assoreamento de corpos d'água; (d) por lagoas multifuncionais, parte da Tecnologia Viva de tratamento de águas cinzas (oriundas de pias, tanques, máquinas de lavar, chuveiros), funcionando como lagoas de polimento dos efluentes tratados e reservação de água. Águas pretas (oriundas dos vasos sanitários), por sua vez, formam outra tecnologia viva, composta por duas câmaras anaeróbias seguidas de um banhado construído, vala de infiltração e linha de bananeiras, que absorvem água e nutrientes após tratamento resultando em frutos que são consumidos pelos moradores. A biomassa das plantas do banhado construído, bem como das bananeiras pós-produção, são compostadas ou semi-incorporadas ao solo, liberando nutrientes à medida que sofrem a ação de decompositores (microrganismos, larvas, insetos, pequenos animais), sendo reaproveitados por frutíferas (citricos, pessego, mamão, maracujá, amora, pitanga, graviola, ingá, etc), leguminosas (soja, feijões, guandu, leucena, etc), hortaliças diversas (cenoura, alface, rúcula, etc) e espécies nativas da mata atlântica e exóticas, incorporadas ao sistema para formação de pequena agrofloresta (ipês, açai, araucária, pau-brasil, jequitibá, nim, cedro, urucum, etc), além de flores diversas (capitão, cosmos, orquídeas, etc), milho, cabaça e abóbora, dentre outras.

Buscou-se, dessa forma, construir moradias com maior eficiência, conforto, valor agregado e responsabilidade socioambiental, aproximando as casas e terrenos de espaços mais sustentáveis, complexos, transdisciplinares e biofílicos. 


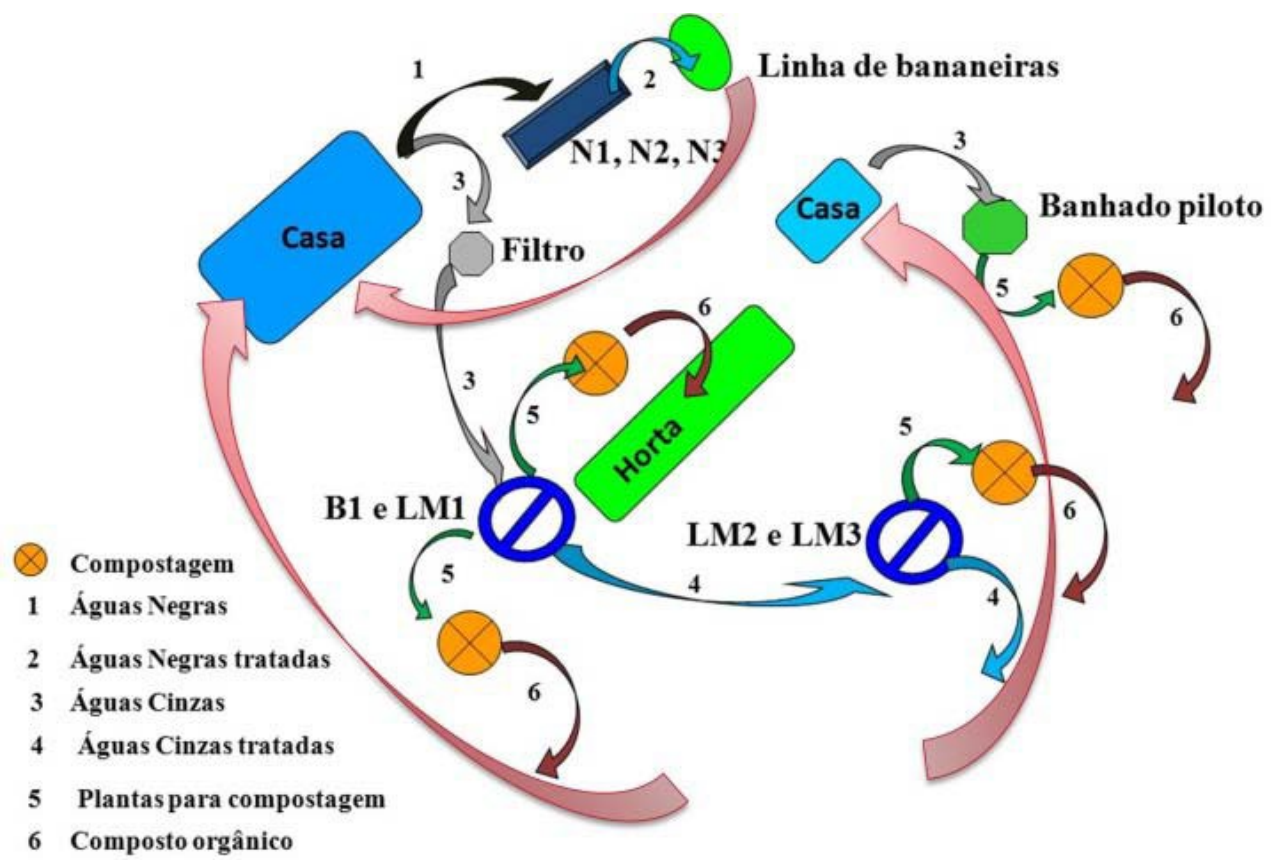

Figura 11. Fluxos de matéria e energia nas Tecnologias Vivas (SANGUINETTO, 2010).

\section{CONSIDERAÇÕES FINAIS}

Entendendo que a Vida é a mestra primeira quando se busca pela sustentabilidade, uma vez que permanece e evolui no planeta há quase 4 bilhões de anos, é nos processos vitais que se pode buscar os conhecimentos básicos para evoluir a sociedade humana a um patamar sustentável em relação ao planeta que habita. Dessa forma, partiu-se não de condições controladas de laboratório, mas de tentativas de reproduzir sistemas naturais em microescala que permitam solucionar problemas relacionados a assentamentos humanos que se deseja sustentáveis, num futuro próximo.

Em certo sentido, inverte-se a lógica da Ciência Clássica, que fraciona a realidade para compreendê-la, mecanizando processos, linearizando e reduzindo relações complexas e especializando o entendimento de mundo, para agora reproduzir a diversidade de vida e as relações e teias que tece em sua relação com o meio, para em seguida medir, analisar e refletir sobre os resultados que se obtém por meio desta abordagem.

Explicando a evolução por meio do acoplamento estrutural entre unidades autopoiéticas e ambiente, propondo ainda que é o Amor o elo que permite a evolução das sociedades humanas, a teoria de Maturana e Varela (2001) embasou a concepção de casas e terrenos como uma unidade autônoma organizacionalmente fechada e 
estruralmente aberta, na esperança de que um dia se comporte como uma unidade autopoiética em sinergia com o ambiente natural e construído. Caso se alcance este estágio, o sistema deverá se desdobrar ou se "reproduzir" em sistemas semelhantes tanto na microbacia como na biorregião, evoluindo ou contribuindo para ultimar em uma Comunidade Sustentável.

O fractal conhecimento-ação apresentado na concepção, implantação e validação das Tecnologias Vivas encontra ecos e faz parte de uma ação mais ampla e complexa, originando outros níveis de realidade que buscam apaziguar os contraditórios em Gaia Terranova (Figura 12):

a. Nível de Realidade 1 - casa e terreno dissociados e a idéia de que o desenvolvimento e permanência do humano no planeta se dá às custas do ambiente natural, que deve ser "dominado" e a "impossibilidade" de se viver de maneira harmônica com o meio estão presentes no modo como vivemos e moramos, criando o primeiro contraditório.

b. Nível de Realidade 2 - a superação do primeiro contraditório se deu por meio do design de tecnologias vivas, biofílicas, amigáveis em relação ao ambiente e biosfera, promotoras da vida, baseadas em modelos ecológicos que promovem a ponte e interações entre casa (casa ecológica) e terreno (habitat sustentável). Estas por sua vez podem ser vistas como um contraditório às tecnologias duras, expressas pelas tecnologias tradicionais baseadas em modelos mecânicos;

c. Nível de Realidade 3 - a Educação para a Sustentabilidade promove a compatibilização entre diferentes visões de mundo, que por sua vez concebem diferentes tecnologias. A educação para a sustentabilidade, ao propor uma visão mais ampla de mundo e educação, mostra-se aparentemente em contradição com a educação tradicional, fruto do pensamento cartesiano e da visão mecânica de universo que fraciona a realidade e especializa o conhecimento e desenvolveu a Ciência baseada na Razão.

d. Nível de Realidade 4 - as Comunidades Sustentáveis marcam a transição de saberes, fazeres, conceitos e práticas insustentáveis rumo à sustentabilidade, fomentando uma convivência harmoniosa dentro do tecido social e deste com a biosfera. Os processos de produção de bens, produtos e serviços estão agora em sintonia com os processos vivos e a humanidade passa a se ver como um todo indissociado da biosfera, parte integrante do sistema que mantém a vida no planeta. 


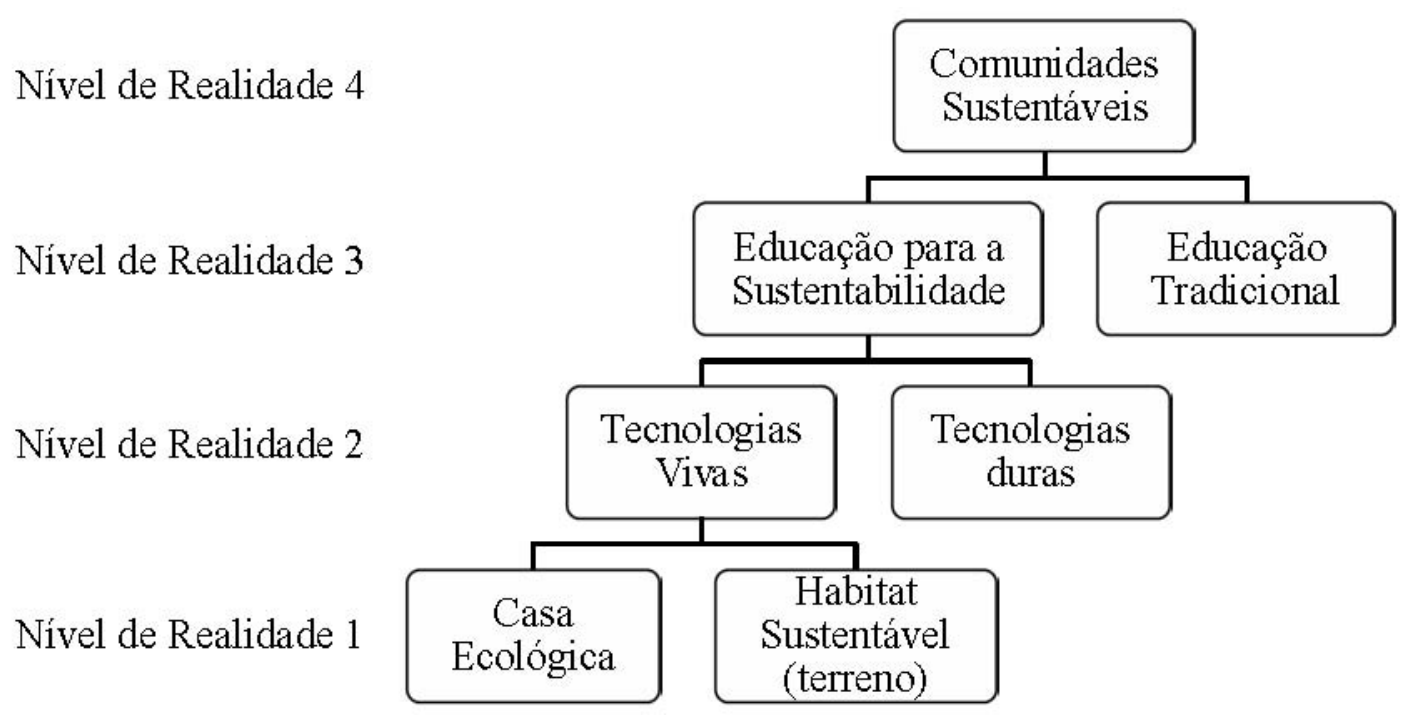

Figura 12: Níveis de Realidade e par de contraditórios em Gaia Terranova.

Com esse trabalho esperamos, modestamente, contribuir para a discussão, evolução e integração de diferentes disciplinas e práticas, inferindo que uma Arquitetura da Complexidade possa auxiliar nossa sociedade na árdua tarefa de superar o atual estágio de dissociação em relação à biosfera e ao planeta que a abriga, construindo pontes que nos permitam inaugurar uma era de cultura de paz em sintonia, harmonia e coevolução com a Vida Planetária.

\section{REFERÊNCIAS BIBLIOGRÁFICAS}

CAPRA, Fritjof. A teia da vida: uma nova compreensão científica dos sistemas vivos. São Paulo: Cultrix, 2006.

FRANCO, Maria de Assunção Ribeiro. Desenho ambiental: uma introdução à arquitetura da paisagem com o paradigma ecológico. $2^{\mathrm{a}}$ edição. São Paulo: Anablume e Fapesp, 2008.

GARDNER, Howard. Inteligências Múltiplas, a teoria na prática. Porto Alegre: Artmed, 1995.

GOLEMAN, Daniel. Inteligência Emocional. Rio de Janeiro: Objetiva, 1996.

MATURANA, Humberto R. e VARELA, Francisco J.. A árvore do conhecimento: as bases biológicas da compreensão humana. São Paulo: Palas Athena, 2001. 
MOLLISON, Bill. Introdução à Permacultura. Tyalgum, Austrália: Tagari Publications. $2^{\mathrm{a}}$ Edição, 1994. Edição brasileira: Rede Brasileira de Permacultura.

MORIN, Edgar. Os sete saberes necessários à educação do futuro. $6^{a}$ edição. São Paulo: Cortez. Brasília, DF: UNESCO, 2002.

MORIN, Edgar. A cabeça bem-feita: repensar a reforma, reformar o pensamento. $8^{\mathrm{a}}$ edição. Rio de Janeiro: Bertrand Brasil, 2003.

NICOLESCU, Basarab. 0 manifesto da transdisciplinaridade. São Paulo: TRIOM, 1999.

SANGUINETTO, Evandro. Design Ecológico: projetando e construindo tecnologias vivas para o tratamento de efluentes domésticos com reúso das águas. Dissertação. Mestrado em Meio Ambiente e Recursos Hídricos - MEMARH. Universidade Federal de Itajubá - UNIFEI. Itajubá: 2010, 228p.

\footnotetext{
${ }^{1}$ Autopoiese ou autopoiesis (do grego auto «próprio», poiesis «criação») é um termo cunhado na década de 1970 pelos biólogos e filósofos chilenos Francisco Varela e Humberto Maturana para designar a capacidade dos seres vivos de produzirem a si próprios. Segundo esta teoria, um ser vivo é um sistema autopoiético, caracterizado como uma rede fechada de produções moleculares (processos), onde as moléculas produzidas geram com suas interações a mesma rede de moléculas que as produziu. A conservação da autopoiese e da adaptação de um ser vivo ao seu meio são condições sistêmicas para a vida. Por tanto um sistema vivo, como sistema autônomo está constantemente se autoproduzindo, autorregulando, e sempre mantendo interações com o meio, onde este apenas desencadeia no ser vivo mudanças determinadas em sua própria estrutura, e não por um agente externo. In http://pt.wikipedia.org/wiki/Autopoiese
}

${ }^{2}$ Ver o sítio http://mandelbrot.ovh.org/ onde se pode experimentar a criação on line de fractais.

${ }^{3}$ Fonte: http://imgsrc.hubblesite.org/hu/db/images/hs-2007-41-a-large_web.jpg 
${ }^{4}$ Deve-se entender por nível de Realidade um conjunto de sistemas invariantes sob a ação de um número de leis gerais: por exemplo, as entidades quânticas submetidas às leis quânticas, as quais estão radicalmente separadas das leis do mundo macrofísico. Isto quer dizer que dois níveis de Realidade são diferentes se, passando de um ao outro, houver ruptura das leis e ruptura dos conceitos fundamentais (como por exemplo, a causalidade). Nicolescu (1999), p. 25.

${ }^{5}$ A lógica clássica está baseada em três axiomas: (a) Identidade: A é A; (b) Não-contradição: A não é não-A; (c) Terceiro excluído: não existe um terceiro termo T (de terceiro incluído) que é ao mesmo tempo A e não-A. No entanto, com o advento da física quântica, essa lógica tem sido questionada. Nicolescu (1999) aborda a questão dizendo que a lógica quântica introduz diferentes percepções, valores e verdades ao axioma da não-contradição, superando a visão binária por outra onde a Realidade se reveste de diferentes níveis e um terceiro termo $\mathrm{T}$, que seja ao mesmo tempo $\mathrm{A}$ e não-A torna-se possível. No nível da mecânica clássica, por exemplo, onda e partícula são mutuamente excludentes: ou uma ou outra, e a luz não pode ser devidamente explicada, uma vez que se comporta como onda e partícula ao mesmo tempo. No entanto, para a mecânica quântica essa contradição desaparece, pois a dualidade é vista sob um nível de realidade diferente, onde um terceiro elemento "pacifica" a dualidade, incorporando onda e partícula como quantum, quantidade elementar, indivisível de energia eletromagnética.

${ }^{6}$ Ver http://pt.wikipedia.org/wiki//nteligências_múltiplas

${ }^{7}$ Biorregião: Espaço geográfico que contém um ou vários ecossistemas e se caracteriza por sua topografia, vegetação, cultura e história humanas comuns (MOUSINHO apud TRIGUEIRO, p.339, 2003). 